5. Митина Л. Н. Личностное и профессиональное развитие человека в новых социально-экономических условиях / Л. Н. Митина // Вопросы психологии. - 1977. № 4 -С. 29-32. 6. Онищук Л. А. Фундаментальність - категорія якості освіти та освіченості сучасної людини / Л. А. Онищук// Шлях освіти. - 2011. - № 2 (60). C. 15-20.

\title{
АНАЛІЗ СТАНУ ПРОБЛЕМИ РОЗВИТКУ ПРОФЕСІЙНО ЗНАЧУЩИХ ЯКОСТЕЙ УЧИТЕЛЯ ТЕХНОЛОГІЇ В ПІСЛЯДИПЛОМНІЙ ОСВІТІ
}

Ковальчук I. М. Аналіз стану проблеми розвитку професійно значущих якостей учителя технології в післядипломній освіті.

У статті виявлено та проаналізовано результати стану обізнаності вчителів щодо сутності, змісту сучасних професійно значущих якостей учителя технології й методів їх розвитку та рівень готовності вчителя технології до професійного самовдосконалення. Визначено, що в переважної більшості вчителів технології наявний розрив між бажанням бути фахівцем своєї справи і реальними здібностями в досягненні зазначеної мети, між зовнішнім прагненням учителя до професійного зростання та відповідним достатнім рівнем внутрішньої мотивації.

Ключові слова: професійно значущі якості, технологічні якості, самовдосконалення, мотивація, самооцінка.

Ковальчук И. М. Анализ состояния проблемы развития профессионально значимых качеств учителя технологии в последипломном образовании.

В статье определены и проанализированы полученные результаты представлений учителей о сущности, содержании современных профессионально значимых качеств учителя технологии, методах их развития, а также уровень мотивационной готовности учителя технологии к профессиональному самосовершенствованию. Определено, что в подавляющем большинстве существует разрыв между желанием учителей технологии быть профессионалом своего дела и реальными способностями в достижении этой цели, между внешним стремлением учителя к профессиональному росту и соответствующим достаточным реальным уровнем внутренней мотивации.

Ключевые слова: профессионально значимые качества, технологические качества, самосовершенствование, мотивация, самооценка.

Kovalchuk I. M. The analysis into the problem of developing professionally significant qualities of a Technology teacher in postgraduate education.

The article defines and analyzes the obtained results as for teachers' idea about the gist and meaning of present-day professionally significant qualities of a Technology teacher, methods of their development as well as the level of motivational readiness of a Technology teacher to professional self-perfection. The author determines that in most cases there is a gap between a Technology teacher's desire to be an expert in his/her sphere and actual abilities to reach the goal, between teacher's outward urge towards professional selfperfection and relevant level of inward motivation

Key words: professionally significant qualities, technological qualities, self-perfection, motivation, self-appraisal. 
Сучасний учитель технології із сформованим рівнем розвитку професійно значущих якостей (далі ПЗЯ)є однією із ключових фігур, що визначає рівень ефективності процесу й результату всіх ланок технологічної освіти. Тенденції розвитку педагогічної науки і практики актуалізуються широким упровадженням у педагогічний процес діагностичного інструментарію як найважливішого засобу у формуванні та отриманні достовірної інформації про якісний стан та вивчення позитивної динаміки змін досліджуваного об'єкта.

Діагностувальний підхід дозволяє досліджувати процеси та об'єкти 3 точки зору виявлення норми й патології (відхилення від норми). Метою діагностувального підходу є постановка діагнозу досліджуваному об'єкту на основі розробленої системи критеріїв та показників, тобто формулювання обгрунтованого висновку щодо предмета вивчення [4]. Проблема педагогічного діагностування розглядається у працях В. Беспалько, В. Звєревої, І. Інгенкампа, І. Підласого, В. Шадрікова, Т. Шамової та ін.

Метою статmі є виявлення загального стану проблеми розвитку професійно значущих якостей учителя технології в післядипломній освіті.

Задля реалізації поставленої мети на попередньому етапі було здійснено аналіз наукової психолого-педагогічної літератури, нормативних документів, що характеризують історичні аспекти, основні теоретичні основи витоків професійно значущих якостей учителя технології, сучасний етап розвитку технологічної освіти, 3'ясовувались проблемні зони зазначеного питання, розроблено систему критеріїв, показників і рівнів сформованості ПЗЯ вчителя технології.

На цьому етапі передбачається виявити стан проблеми розвитку ПЗЯ вчителя технології в післядипломній освіті, у зв'язку з чим застосовувались методи бесіди, педагогічного спостереження (у процесі курсів підвищення кваліфікації), опитування, анкетування, інтерв'ювання, тестування.

Відповідно до сучасних змін у технологічній освіті ми визначили інтегративні групи ПЗЯ вчителя технології, з-поміж яких - культура професійної самосвідомості, технологічна культура, комунікативна культура і креативна культура.

У дослідженні брали участь 251 працюючий учитель технології Дніпропетровської та Чернігівської областей протягом 2012-2013 навчального року на базі інститутів післядипломної педагогічної освіти у процесі курсів підвищення кваліфікації: 59 \% жінки і $41 \%$ чоловіки. Серед них: 56 \% учителів вищої категорії, $30 \%$ - першої, 14 \% - другої категорії та спеціаліст.

Основними напрямами у виявленні стану проблеми розвитку ПЗЯ вчителя технології стали: діагностування рівня обізнаності вчителів технології щодо змісту, сутності сучасних професійно значущих якостей і методів їх розвитку; виявлення рівня мотиваційної готовності вчителя технології до професійного самовдосконалення в післядипломній освіті.

Задля вивчення обізнаності вчителів щодо ПЗЯ, актуальних на сучасному етапі розвитку технологічної освіти, ми запропонували вчителям технології заповнити анкету «Виявлення уявлень учителів технології щодо професійно значущих якостей», яка містила питання відкритого типу. Прослідкуємо особливості розуміння вчителем сучасних об'єктивних змін у технологічній освіті учнів, суб'єктивних уявлень щодо ПЗЯ вчителя технології та усвідомлення проблеми їх розвитку.

У відповідях на перше питання «Які зміни, на Вашу думку, відбуваються в сучасній технологічній освіті учнів протягом останніх 15 років?» $32 \%$ вчителів, хоча $і$ не повною мірою, але відчувають позитивні зміни. Як правило, вчителі називали 
окремі, не більше однісї-двох, інколи трьох інноваційних ознак сучасної технологічної освіти, серед них: проектне навчання, інтегративність та варіативність змісту, перехід до розвитку мислення, посилення ролі самостійної активності учнів, упровадження комп'ютерних, інтерактивних технологій навчання, спрямування на креативний розвиток особистості.

Думку про те, що суттєвих змін у технологічній освіті не відбулось, висловили $24 \%$ вчителів; мали утруднення дати відповідь $32 \%$; лише негативні зміни відзначили $12 \%$. Як видно із вищезазначеного, вчителями недостатньо відчуваються тенденції розвитку й сучасні вимоги до реалізації завдань технологічної освіти учнів. Недостатня сформованість креативної культури вчителя не дозволяє вийти за межі майстерні, розкрити нові можливості, що криються в технологічній освіті, а також у здібностях учителя сприймати, бачити, відчувати інновації, бути готовим до них i користуватися ними.

Виконання завдання: «Розкрити сутність поняття «професійно значущі якості вчителя технології» показало, що учасники опитування розділились на три частини: $6 \%$ учителів були близькі до правильної відповіді і визначили ПЗЯ вчителя як «якості, що $є$ запорукою успішного навчально-виховного процесу або досягнення педагогічних цілей»; 40 \% не змогли дати відповідь; 54 \% опитуваних наводили лише перелік особистісних якостей, що не відображає повноти сформованості поняття та розуміння сутності зазначеного феномену.

У визначенні вирішальних чинників розвитку ПЗЯ думки вчителів розділились на дві групи. Учителі технічної праці (38\%) до чинників розвитку ПЗЯ включили окремі внутрішні індивідуально-особистісні якості: «інтерес, бажання, любов до професії, потреби, цілеспрямованість». Група вчителів обслуговуючої праці (58 \%) у складі основних чинників розвитку ПЗЯ людини бачать, навпаки, зовнішні: «курси підвищення кваліфікації, відвідування лекцій, семінарів, спілкування 3 іншими вчителями, використання мережі Інтернет, відвідування майстер-класів». Отже, недооцінка внутрішніх (суб'єктивних) чинників - станів людини, пов'язаних із сформованими особливостями індивідуальних, особистісних, духовних якостей, а також зовнішніх (об'єктивних) чинників - соціального устрою суспільства, культурно-технологічного середовища свідчить про недостатнє розуміння вчителями їх взаємозв'язку, взаємозумовленості та цілісності як основної рушійної сили самовдосконалення людини, так і розвитку навколишнього світу.

Слід додати, що не було зосереджено уваги вчителів на чинниках виховання та самовиховання, роль яких полягає у формуванні цінностей, потреб, цілей, переконань, сходженню до розуміння людиною власної духовності.

За результатами виконаного завдання: «Назвати ПЗЯ вчителя технології, актуальні на цьому етапі розвитку технологічної освіти учнів», ми отримали: дидактичні якості - знання, уміння, навички і вміння донести матеріал до учнів (56 \%); професіоналізм - 30\%; комунікабельність - $20 \%$; володіння передовими технологіями - $15 \%$; володіння комп'ютером, компетентність, креативність - 12,5\%; моральні та вольові якості $11 \%$; здатність до самоосвіти - 8 \%. Окрім того, $16 \%$ не визначились $з$ сучасними якостями вчителя технології.

Сформованість ПЗЯ в уявленнях більшості вчителів технології з професійними знаннями, уміннями, навичками та вмінням передавати їх учням залишає поза увагою інші глибинні сторони професіоналізму педагога. Такий підхід можна пояснити тим, що освіта як процес тривалий час ототожнювалась переважно із навчанням, надаючи функціям виховання та розвитку другорядну роль, що неминуче призводить до нівеляції духовного складника змісту освіти. 
Водночас, задля ефективного формування технологічних якостей в учнів та професійного самовдосконалення вчителю необхідно володіти достатньо широким спектром методів. Розглянемо, на які методи вказують вчителі у формуванні якостей. Відтак, 31 \% учителів адекватно уявляють методи, а саме: інтерактивні методи, бесіди, дискусії, мозковий штурм, проекти, екскурсії, участь в олімпіадах, конкурсах, виставках, ознайомлення з професіями; 32 \% - обмежились теоретичним і практичним виконанням роботи; $37 \%$ мали утруднення 3 відповідями. Отже, менше половини вчителів мають адекватне уявлення про методи розвитку якостей, а сам набір методів достатньо обмежений і зводиться переважно до дидактичних, інформаційних методів: наочних і словесних. До того ж учителі часто не диференціюють поняття «метод» $\mathrm{i}$ «форма». Проте саме методи в діяльності вчителя визначають способи взаємодії між учасниками педагогічного процесу, способи досягнення цілей, розвивають здібності, професійні якості та постають показником рівня професіоналізму вчителя.

У той же час цікаво було дізнатися, з яких джерел вчителі мають уявлення щодо ПЗЯ вчителя технології. У своїх відповідях 64 \% вчителів виокремили Інтернет, фахові журнали, методичну літературу, курси підвищення кваліфікації; 30 \% джерелами знань визначили спілкування, відвідування уроків, майстер-класів; і лише $6 \%$ - професійне навчання. Це може свідчити про недостатність уваги, що приділяється формуванню та розвитку ПЗЯ майбутнього вчителя технології в період професійного навчання.

Отже, можна зазначити, що сучасний учитель недостатньо володіє проблемою розвитку ПЗЯ. Сформованість суб'єктивних уявлень учителів технології щодо ПЗЯ та їх розвитку $є$ фрагментарними, неструктурованими. Учитель не завжди усвідомлює, що, з одного боку, важливим джерелом знань та розвитку ПЗЯ є внутрішній світ людини: індивідуальні природні, особистісні, духовні якості, власний світогляд, процес мислення та самосвідомість. Цікавою 3 цього приводу є думка А. Карпова, який стверджує, що рефлексивні здібності «є перш за все засобом і каналом отримання та декодування інформації» [3, с. 61]. 3 іншого боку, довкілля, 3 його вимогами 3 боку держави, потреб соціуму, інноваційними змінами в освіті, навчальних програмах, нових педагогічних ситуаціях і обставинах пропонує напрями змін людині.

Для нашого дослідження важливо виявити мотиваційну готовність вчителя до розвитку ПЗЯ. Одним із чинників, що надає внутрішньої сили, сприяє мотивації, надихає до творчості вчителя, формує смисл професійної діяльності, є почуття успіху й задоволеності професією. Проведене анкетування, на основі методики, розробленої Н. Журіним та Є. Ільїним [1, с. 465], показало, що вчителі відчувають багато неоднозначних почуттів у виявленні власної професійної успішності. На наш погляд, цікаво відстежити динаміку рівня незадоволеності вчителів за параметрами, на які найбільш часто вказують учителі в анкетах.

Як видно на рисунку 1, на вищому рівні вияву незадоволеності вчителів професійною діяльністю перебувають зовнішні чинники: матеріально-технічне забезпечення предмета (90\%), заробітна плата вчителя $(77,5$ \%). Слід визнати, що незадоволеність рівнем заробітної плати є стримуючими чинниками професійного самовдосконалення. 


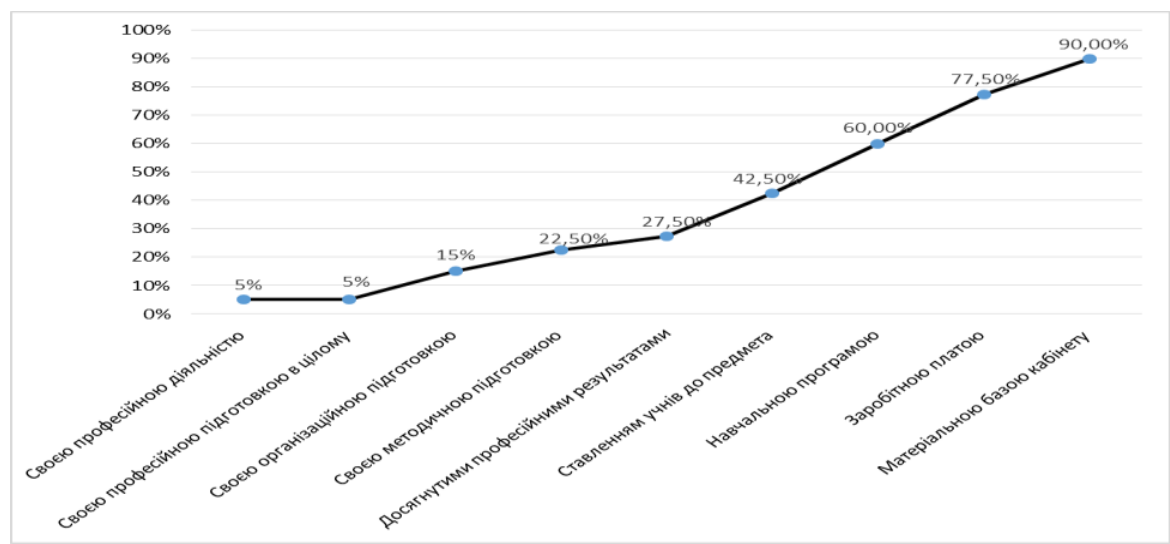

Рис. 1. Вияв рівнів незадоволеності вчителів технологї за параметрами професійної діяльності

Однак, «...дослідження психологів уже на початку 20-х років XX століття показали, що ... заробітна плата є не єдиним засобом посилення мотивів трудової діяльності людини» [1, с. 304]. Важливу роль у професійному зростанні відіграють саме нематеріальні мотиви - соціальні та психологічні, такі, як: бажання виховувати, навчати учнів, досягати результатів.

Звернемо увагу на такий факт: негативні почуття щодо ставлення учнів до предмета мають 42,5\% учителів, а самокритика вчителів до професійної, організаційної та методичної підготовки має межі від 5 \% до 22,5\%. Тобто часто проблеми пояснюються зовнішніми причинами. Однак не меншу роль у їі розв'язанні відіграє правильне визначення вчителем рівня свого професійного розвитку, здібностей, адекватна оцінка дійсності, здатність вчителя до самоаналізу. Так, В. Сухомлинський наголошував: «Чим глибше люблять ваші вихованці предмет, який ви викладаєте, тим кращий ви педагог, тим органічніше зливаються у вашій особистості вихователь і викладач» [5, с. 152]. Таку ж тенденцію підтверджують у своїх дослідженнях Т. Мальковська і В. Зацепін [2, с. 427].

За результатами оброблення даних анкет, можна констатувати, що у визначенні власної професійної успішності перевагу позитивних емоцій складають - 57,5\% учителів; середній рівень задоволеності відчувають $37 \%$; на фоні високого рівня незадоволеності працюють - 5,5\%.

Однією із важливих властивостей сучасного фахівця $\epsilon$ спрямованість на самовдосконалення, що впливає на якість педагогічної діяльності та характеризує ставлення вчителя до професійних обов'язків. Задля отримання інформації щодо стану мотиваційної готовності вчителів до професійного самовдосконалення ми розробили анкету «Самооцінка професійного самовдосконалення вчителя технології».

Отримані дані самооцінки професійного самовдосконалення вчителів технології свідчать, що високий рівень мають 27,6 \% учителів; середній - 66,8 \%; низький $5,5 \%$. Проте під час проведення діагностування самооцінки, для нас важливою була опора на реальні факти, що підтверджують вибори респондентів, а не лише суб'єктивні думки. Тому вчителям було запропоновано виконати деякі завдання. Проаналізуємо отримані результати.

Оскільки важливим кроком на шляху успішної практичної реалізації 
професійного самовдосконалення $€$ правильно поставлена професійна мета, ми запропонували вчителям визначити свої індивідуальні цілі. Проте з'ясувалося, що вони мають надто загальний, навіть абстрактний характер, наприклад: «підвищити професійний рівень», «оволодіти новими знаннями, уміннями, навичками», «йти в ногу 3 часом, відповідати вимогам сучасності», «осягти неможливе, хоча це неможливо» тощо. Беззаперечно, спостерігається позитивне спрямування педагогів. Але як конструктивно їх використовувати, у чому полягає змістовий компонент і чим конкретно необхідно оволодіти?

Отже, невизначеність того, що саме і якими засобами буде реалізована мета, який обсяг роботи необхідно виконати, скільки часу на ії досягнення потрібно і який конкретно результат слід очікувати, відображає швидше декларативний характер професійного самовдосконалення вчителя. Однак, визначені таким способом цілі можуть характеризувати позитивне ставлення вчителя до професійної діяльності та вказувати на мотивацію до професійного зростання. Разом з тим 39 \% вчителів мали утруднення з визначенням мети професійного самовдосконалення.

Дієвим показником ефективної роботи вчителя над собою $є$ відповідно розроблена індивідуальна програма 3 комплексом діяльнісних засобів. Якщо не створено проекту діяльності педагога, спрямованого на свій професійний розвиток, важко отримати результат. Наявність такої програми задекларували 1 \% вчителів; 99 \% визнали, що не мають; 94,2 \% потребують методичної допомоги у ії розробленні. Відзначимо ще один факт: $67 \%$ учителів висловили впевненість, що володіють досвідом професійного самовдосконалення, $16 \%$ - частково володіють. Однак професійно охарактеризувати цей процес змогли лише 7 \% респондентів. Окрім того, 88 \% вказали на те, що їм часто не вистачає часу на самоосвіту. Усі наведені факти підтверджують завищену, неадекватну самооцінку вчителів щодо самовдосконалення, недостатній розвиток культури професійної свідомості та креативної культури.

Узагальнюючи результати здійсненого аналізу вихідного стану проблеми розвитку професійно значущих якостей учителя технології, можемо зробити узагальнення, що: 7 \% учителів усвідомлюють інновації у технологічній освіті, на достатньо високому рівні володіють зазначеною проблематикою; 57 \% мають загальні уявлення щодо інноваційних процесів у технологічній освіті; виявили неструктуровані, фрагментарні знання щодо змісту, сутності та розвитку професійно значущих якостей вчителя технології, які асоціюються з традиційними професійними знаннями, уміннями, навичками; $36 \%$ учителів недостатньо відчувають зміни технологічної освіти, не усвідомлюють актуальних ПЗЯ вчителя та методів їх розвитку.

Загалом учителі показали позитивне ставлення до професійного самовдосконалення, як явища, безперечно, важливого й необхідного, але на практиці усвідомлено реалізованим цей процес буває не завжди. Ще й дотепер він має переважно декларативний характер. У педагогічній практиці наявний певний розрив між бажанням учителя бути фахівцем своєї справи і реальними здібностями в досягненні мети; між зовнішнім, задекларованим прагненням учителя до професійного зростання та відповідним достатнім реальним рівнем внутрішньої мотивації. Отже, назріла потреба в оновленні підходів до підвищення кваліфікації вчителів технології в післядипломній освіті.

Наступним етапом нашого дослідження буде розроблення моделі забезпечення розвитку професійно значущих якостей учителя технології в післядипломній освіті.

\section{Література}

1. Ильин Е. П. Мотивация и мотивы / Е. П. Ильин. - СПб. : Питер, 2008. - 512 с. 
2. Ильин Е. П. Психология для педагогов / Е. П. Ильин. - СПб. : Питер, 2012. - 640 с. 3. Психология профессионального педагогического мышления / под ред. М. М. Кашапова. - М. : Институт психологии РАН, 2003. - 398 с. 4. Санжиева Я. Б. Разработка и применение программы мониторинга профессионального развития учителя // Научные записки Забайкальского государственного университета. Серия: Профессиональное образование, теория и методика обучения. Выпуск № 6 (53) / 2013. Научная библиотека КиберЛенинка: - Режим доступа: http://cyberleninka.ru/article/n. 5. Сухомлинский В. А. Сто советов учителю / В. А. Сухомлинский. - К. : Рад. школа, 1984 - 254 с. - (Пед. б-ка).

\section{ФОРМУВАННЯ ПРОФЕСІЙНОЇ МАЙСТЕРНОСТІ СТУДЕНТІВ ХУДОЖНЬО-ГРАФІЧНИХ ФАКУЛЬТЕТІВ}

Кудренко Д. О. Формування професійної майстерності студентів художньографічних факультетів.

У статті 3'ясовано поняття «професійна майстерність» та «компетентність» студентів художньо-графічних факультетів у контексті образотворчої й декоративноприкладної діяльності. Визначено групи фахових умінь, які є обов'язковими для студентів художньо-графічних факультетів у здійсненні професійної діяльності.

Ключові слова: професійна майстерність, компетентність, професійні уміння, професійна діяльність, декоративно-прикладна діяльність.

Кудренко Д. А. Формирование профессионального мастерства студентов художественно-графических факультетов.

В статье раскрываются понятия «профессиональное мастерство» и «компетентность» студентов художественно-графических факультетов в контексте изобразительной и декоративно-прикладной деятельности. Определены группы профессиональных умений, которые являются обязательными для студентов художественно-графических факультетов в осуществлении профессиональной деятельности.

Ключевые слова: профессиональное мастерство, компетентность, профессиональные умения, профессиональная деятельность, декоративно-прикладная деятельность.

Kudrenko D. O. Forming professional skills of students at art-graphic departments.

The article reveals the concept of "professional skills" and "competence" of students at art-graphic departments in the context of the fine arts, decorative and applied activity. The author defines a set of professional skills that are compulsory for students of art-graphic departments in implementating professional activity.

Key words: professional skills, competence, professional abilities, professional activity, decorative and applied activity.

У Національній доктрині розвитку освіти в Україні у XXI столітті визначено головну мету, яка полягає у створенні умов для особистісного розвитку та творчої самореалізації кожного громадянина України, формуванні покоління, здатного навчатися впродовж усього життя, створювати та розвивати цінності громадянського суспільства; інтеграції України в європейський i світовий простір як 